\title{
Feline hypertrophic cardiomyopathy: an echocardiographic approach
}

\author{
Cardiomiopatía hipertrófica felina: enfoque ecocardiográfico \\ AC Silva ${ }^{a *}$, RAL Muzzia ${ }^{a}$ G Oberlender ${ }^{b}$, RB Nogueira ${ }^{a}$, LAL Muzzi ${ }^{a}$ \\ aDepartment of Veterinary Medicine, Division of Small Animal Medical Clinic, \\ Federal University of Lavras, Lavras, Minas Gerais, Brazil. \\ bDepartment of Veterinary Medicine, Division of Physiology and Pharmacology, \\ Federal University of Lavras, Lavras, Minas Gerais, Brazil.
}

\begin{abstract}
RESUMEN
La cardiomiopatía hipertrófica felina es una enfermedad primaria del miocardio que se caracteriza por una leve a severa hipertrofia concéntrica primaria del miocardio ventricular. Los factores hereditarios y mutaciones causales se han atribuido al desarrollo de la enfermedad en algunas razas, como los gatos Maine Coon y Ragdoll. Sin embargo, esta enfermedad sigue siendo un reto para los veterinarios debido a la dificultad del diagnóstico precoz y el riesgo de muerte súbita de los animales afectados. La ecocardiografía es una herramienta no invasiva de elección para el diagnóstico de las enfermedades cardíacas en los gatos. Nuevas técnicas ecocardiográficas como el Doppler Tesidual (el color bidimensional, el modo M a color y el modo de onda pulsada), Strain y Strain rate, han demostrado ser eficaces en el diagnóstico temprano de la disfunción del miocardio, incluso en ausencia de hipertrofia en el examen ecocardiográfico convencional. Esta revisión pretende acercar la información más reciente sobre el diagnóstico ecocardiográfico de la cardiomiopatía hipertrófica felina.
\end{abstract}

Key words: feline, echocardiography, diagnosis, myocardial hypertrophy.

Palabras clave: gatos, ecocardiografía, diagnóstico, hipertrofia del miocardio.

\section{INTRODUCTION}

Hypertrophic cardiomyopathy is one of the most frequent familial cardiac diseases in humans and occurs similarly in cats, in which $57 \%$ of idiopathic cardiomyopathies are represented by the hypertrophic form and are diagnosed in 15\% of apparently healthy animals (Page et al 2009, Payne et al 2010). HCM continues to be a challenging disease for veterinarians because it remains the major cause of morbidity and mortality in cats and it is associated with risk of sudden death, heart failure and arterial thromboembolism (Chetboul et al 2006a).

Definitive diagnosis of feline HCM is mainly based on echocardiography, which is the method of choice to observe structural changes and evaluate pathological dysfunctions (Brizard et al 2009, Wess et al 2010). Studies have demonstrated that HCM was the most frequent alteration observed during echocardiography examination conducted in apparently healthy cats (Paige et al 2009, Nakamura et al 2011). Regarding this tool, a large number of echocardiographic methods are used in feline cardiac diseases (Bonagura 2000), such as conventional echocardiography (M-mode, two-dimensional and classic Doppler as spectral and colour flow) and new Doppler techniques

Accepted: 26.04.2012.

* Caixa postal 3037, CEP 37.200-000, Lavras, Minas Gerais, Brasil; adrianagudi@gmail.com (tissue, strain and strain rate) (Abbott and MacLean 2006, Wess et al 2010, Boon 2011).

Since the echocardiography is the method of choice for the diagnosis of HCM, this study aims to update the echocardiographic approach to feline HCM diagnosis, as this tool is of great importance in guiding clinicians with respect to the diagnosis and management of the disease.

\section{ECHOCARDIOGRAPHIC APPROACH}

In recent years, standard trans-thoracic echocardiography has become a primary imaging tool for the diagnosis and management of small animal cardiovascular diseases (Chetboul 2010). Many echocardiographic formats are used in clinical practice that involve the reflection of ultrasonic waves from cardiovascular tissues, specialised processing of the returned (echoed) signals, and the display of this information in recognizable visual or auditory format (Bonagura 2000).

More recent advances in ultrasound technology, such as tissue Doppler image (TDI), Two-dimensional speckle tracking echocardiography (2D STE), strain (St) and strain rate (StR) imaging, have provided new parameters to assess myocardial function, including regional myocardial velocities and deformation, ventricular torsion and synchrony (Chetboul 2010).

Echocardiography is the most important tool for the diagnosis of myocardial disease in cats, since it identifies structural changes and pathological dysfunction of the 
myocardium. It has been widely used in veterinary practice to provide a non-invasive assessment of cardiac function (Ferasin 2009). It is considered the gold standard exam for feline HCM (Bonagura 2000).

Sedation may be necessary in some animals when echocardiographic examination is made difficult by stressed animals (Ferasin 2009). One study demonstrated that sedation using a combination of acepromazine and hydromorphone does not affect two-dimensional (2D) and M-mode measurements, despite the mild increase in the heart rate (Campbell and Kittleson 2007). In contrast, another study demonstrated that the use of propofol did not alter diastolic function in Maine coon cats with HCM and mildly decreased systolic mitral annular velocity (MacDonald et al 2006). Drugs such as ketamine and xylazine can induce a significant decrease in several echocardiographic variables, such as the diameter of the left atrium (LA), the diameter of the left ventricular lumen in the diastole and fractional shortening (Dümmel et al 1996).

Routine echocardiographic examination in cats must include images obtained from the right and left hemithorax. The 2D and M-mode diastolic measurements must be analysed at end-diastole, which can be identified by the beginning of the QRS complex (Simpson et al 2007, Boon 2011). Images of papillary muscle, mitral valve, aortic root and LA should be obtained by means of $2 \mathrm{D}$ and M-mode techniques. These measurements, primarily of the papillary muscles, left ventricular wall and interventricular septum (IVS), are very useful for diagnosis of hypertrophy (Bonagura 2000), and an inadequate position of leaflets can be observed at the mitral valve level (Fox et al 1995). End-diastolic wall thickness of the IVS and the left ventricular posterior wall (LVPW) must be measured in the basal and mid-ventricular segment of the respective myocardial wall using the right parasternal long-axis view (Wess et al 2010) or right short-axis view (Fox et al 1995). The LA must be interrogated for increased diameter, and attention must be given to the presence of thrombi using 2D measurements (Bonagura 2000). Left ventricular outflow tract, valve flows and myocardium velocity can be examined by using Doppler studies (colour, continuous and pulsed wave and TDI) (Boon 2011). The left apical four-chamber view can be used to assess trans-mitral (figure 1) and trans-tricuspid flow patterns, while the left apical five-chamber view could be used to obtain the aortic flow velocity (Simpson et al 2007, Fuentes 2010, Boon 2011).

M-mode echocardiography provides measurements of myocardial thickness and ventricular diameter during different periods of the cardiac cycle. Some alterations in the mitral valve can be observed with this method, such as inadequate position of leaflets that can cause valve regurgitation or left ventricle outflow tract obstruction (LVOTO) (Ferasin 2009). Two different planes must be obtained, one at the level of the papillary muscles in order to measure the IVS and left ventricular free wall (LVFW) thicknesses in end-diastole and the other at the level of the mitral valve to determine the presence or absence of systolic anterior motion (SAM) (Boon 2011). However, M-mode may fail to show regional hypertrophy (Bonagura 2000) and does not provide information about blood flow, fibrotic lesions or valvular insufficiency. Finally, assessment of RV morphology and function is very difficult in M-mode studies (Ferasin 2009). Some clinical investigations of feline HCM have used an end-diastolic wall thickness equal to or exceeding $6.0 \mathrm{~mm}$ as the primary diagnostic criterion (Koffas et al 2008, Wess et al 2010). However, another study adopted $5.0 \mathrm{~mm}$ as a decision criterion (Brizard et al 2009) (figure 2).

Although the main effects of HCM are due to diastolic dysfunction, systolic indices such as fractional shortening and ejection fraction may be altered in cats affected by HCM (Boon 2011). At the beginning of the disease, such indices may be normal or elevated (Fox et al 1995, Koffas et al 2006), and in the end stages, they may present reduced values (Baty et al 2001, Boon 2011).

Papillary muscle hypertrophy can be one of the only signals that indicates the presence of HCM in some cats as well as human beings (figure 3) (Kobashi et al 1998, Kittleson et al 1999, Adin and Diley-Poston 2007). In one study, measurements of papillary muscle were obtained from 2D and M-mode measurements in normal and HCM cats, which ruled out secondary causes of HCM and showed that those with HCM presented papillary muscle larger than normal cats (Adin and Diley-Poston 2007).

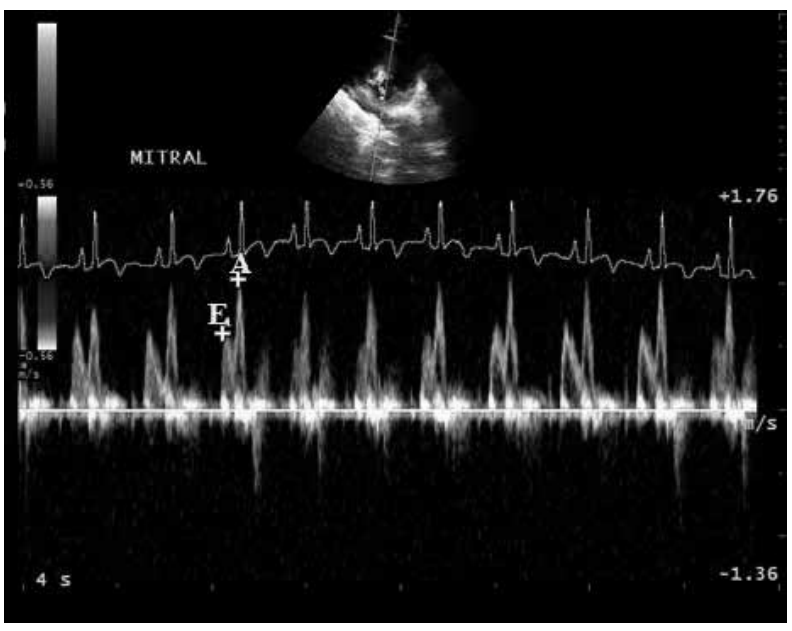

Figure 1. Mitral valve flow obtained from apical parasternal 4-chamber view in a cat with HCM. Note inversion between peak velocity of early diastolic transmitral flow (E wave) and peak velocity of late diastolic transmitral flow (A wave), due to diastolic dysfunction.

Flujo de la válvula mitral obtenido a partir de proyección paraesternal apical 4 cámaras en un gato con cardiomiopatía hipertrófica. Note la inversión entre la velocidad del pico temprano del flujo diastólico transmitral (onda E) y la velocidad del pico final del flujo diastólico transmitral (onda A), debido a la disfunción diastólica. 


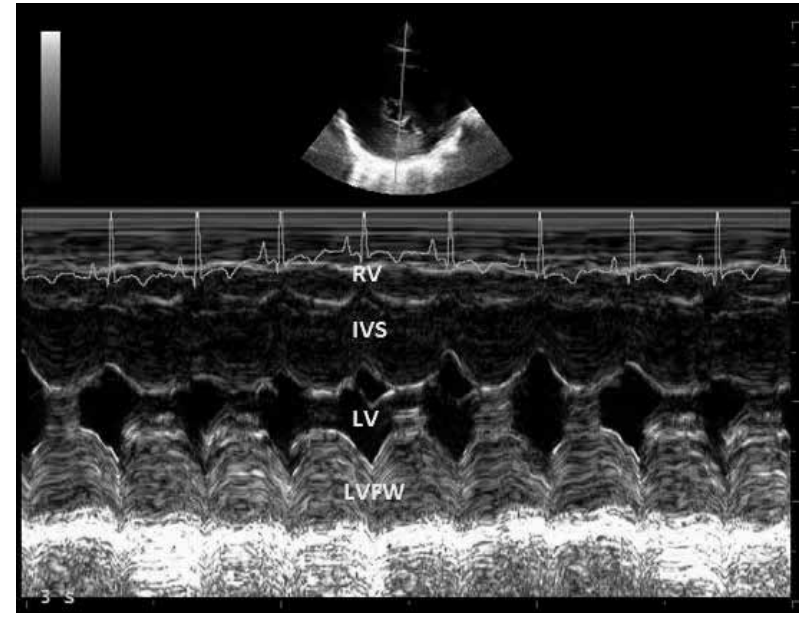

Figure 2. Two-dimensional and M-Mode echocardiographic examination of a cat with $\mathrm{HCM}$ on right parasternal short axis view at the level of the chordae tendineae. Note interventricular septum and left ventricular free wall hypertrophy. LVFW: left ventricular free wall; IVS: interventricular septum and RV: right ventricle.

Examen ecocardiográfico bidimensional y modo $\mathrm{M}$ de un gato con cardiomiopatía hipertrófica a partir de la vista paraesternal derecha eje corto a nivel de las cuerdas tendinosas. Note la hipertrofia de la pared libre del ventrículo izquierdo y del septo interventricular. LVFW: pared libre del ventrículo izquierdo; IS: septo interventricular y RV: ventrículo derecho.

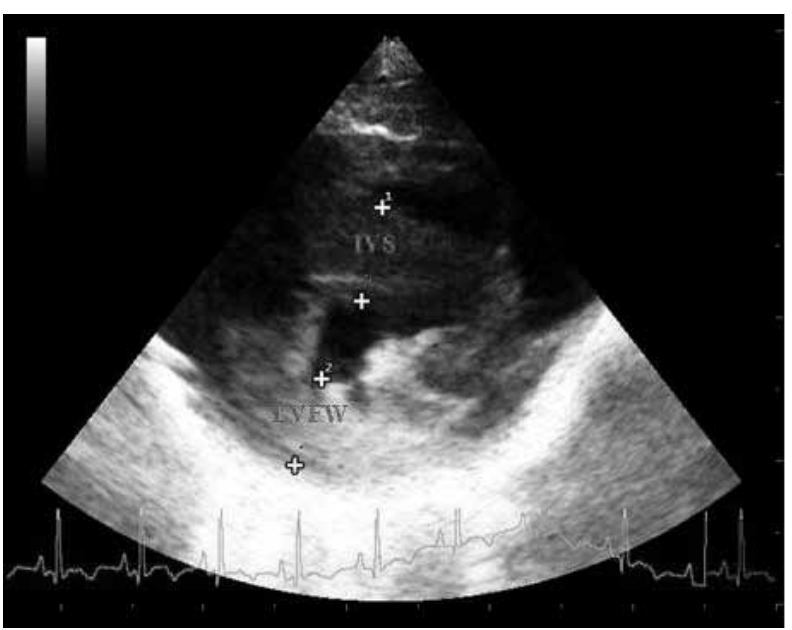

Figure 3. Two-dimensional echocardiographic examination of a cat with HCM from the right parasternal short axis view at the level of the papillary muscles. Note left ventricle free wall and interventricular septum hypertrophy at diastole. IVS: interventricular septum and LVFW: left ventricular free wall.

Examen ecocardiográfico bidimensional de un gato con cardiomiopatía hipertrófica a partir de la vista paraesternal derecha eje corto a nivel de los músculos papilares. Note la hipertrofia de la pared libre del ventrículo izquierdo y del septo interventricular en diástole. IVS: septo interventricular y LVFW: pared libre del ventrículo izquierdo.

The LA size has been associated with ventricular filling pressures in patients with diastolic dysfunction, and this finding is very important to feline cardiology. LA can be accessed by M-mode measurements, though limitations to this technique exist: it is difficult to align the transducer through the body of the atrial chamber (Abbott and MacLean 2006). Therefore, LA final systolic diameter should be measured with 2D studies (Bonagura 2000, Abbott and MacLean 2006). In normal cats, this measure should be $<10.0 \mathrm{~mm}$, and its relationship with the aorta (LA/Ao) must be $<1.5$, as these values may be elevated in HCM cats (Abbott and MacLean 2006, Ferasin 2009). Abbott and MacLean (2006) performed a study comparing measurements of the LA and the relationship LA/Ao by M-mode and 2D measurements, and they observed that the LA obtained by M-mode measurements showed a larger diameter than the 2D measurements. This could be explained by the smaller diameter of the aorta in the M-mode study.

Dynamic LVOTO is a common finding observed in feline HCM. It is an obstructive form of HCM that may cause a turbulent blood flow that could be identified using the colour-flow Doppler (Ferasin et al 2003). This form of $\mathrm{HCM}$ is due to the SAM of the mitral valve leaflets toward the IVS or to hypertrophy of the dorsal IVS that protrudes into the LVOT during systole. Mitral valve insufficiency is frequently observed due to SAM, because abnormal leaflets in the valve result in incomplete cooptation at systole (Abbott 2010, Schober and Todd 2010) (figure 4A and 4B). Mitral valve apparatus, IVS and LVOT can be also observed by using 2D echocardiography (figure 5) (Schober and Todd 2010).

The TDI is an echocardiographic technique that allows quantification of global and regional myocardial function from measurements of myocardial velocities in real time (Chetboul 2002, Simpson et al 2007, Chetboul 2010). Pulsed-wave and colour M-mode are TDI techniques that have been demonstrated to be sensitive tools to detect even mild forms of HCM, providing an early diagnosis of the disease (MacDonald et al 2006, Koffas et al 2006, Koffas et al 2008).

Spectral pulsed-wave TDI is a technique that measures myocardial velocity, which has good temporal resolution (Simpson et al 2007) and has been used to assess the velocities within the feline myocardium (Chetboul et al 2006', Chetboul et al 2006 ${ }^{\mathrm{b}}$, Simpson et al 2007) (figure 6).

Chetboul et al (2006a) using affected cats and carriers of dystrophin-deficient hypertrophic muscular dystrophy as a model of HCM, demonstrated that TDI could detect radial and longitudinal LVFW dysfunction in all cats even though none of the animals presented significant left myocardial hypertrophy. In this same study, those cats with mutations but without LVFW hypertrophy showed larger longitudinal TDI isovolumic relaxation times, longitudinal TDI E'/A' ratios less than 1 at the base and radial TDI E'/A' ratios less than 1 in the sub-endocardium and subepicardium, as well as reduction of systolic longitudinal myocardial velocities at the heart base and apex, when compared with healthy cats. 


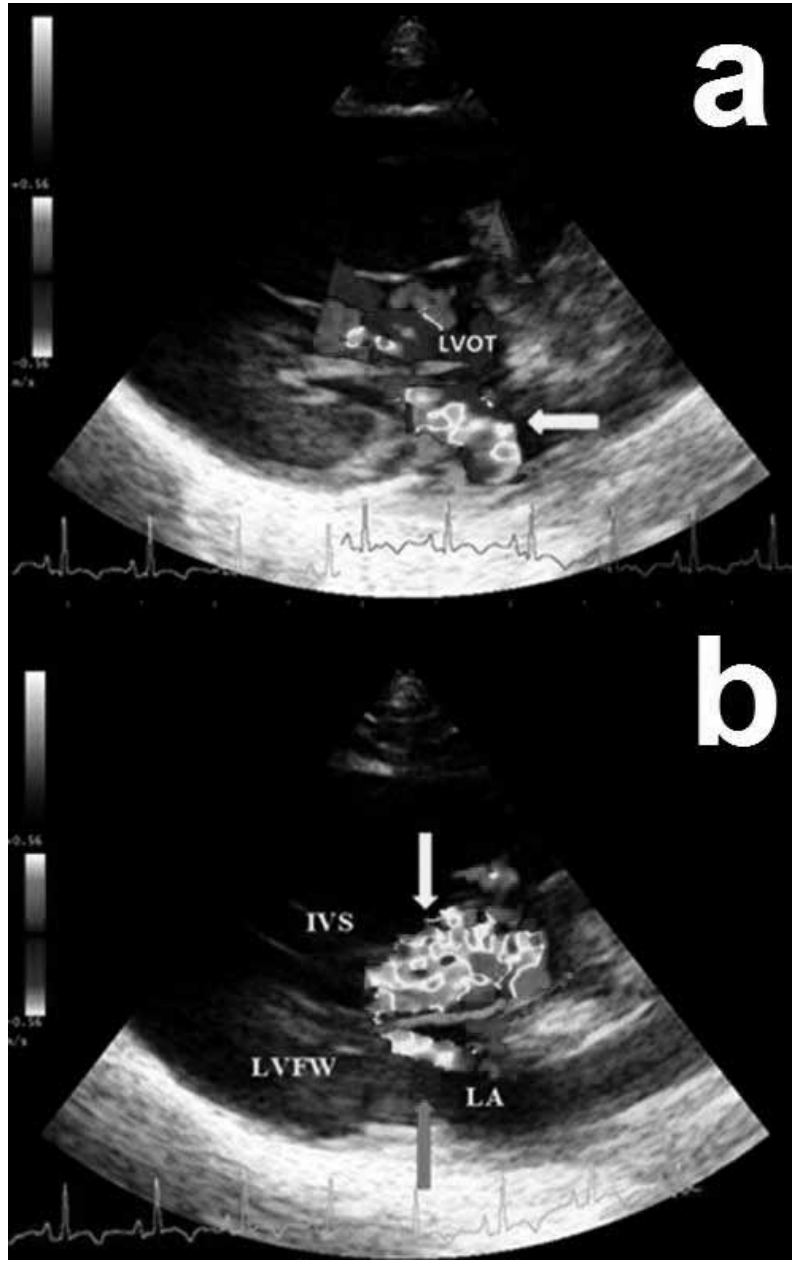

Figure 4. Two-dimensional and color Doppler mode examination of a cat with obstructive HCM in the left ventricular outflow tract from the right parasternal 5-chamber view. (a): Note turbulent flow due to insufficiency of mitral valve to left atrium (yellow arrow). (b): Note turbulent flow at systole in left ventricular outflow tract due to obstruction hypertrophy at the sub-aortic area and at left atrium due to mitral insufficiency (yellow and red arrows, respectively). LVOT: left ventricular outflow tract; LA: left atrium; LVFW: left ventricular free wall and IVS: interventricular septum.

Examen ecocardiográfico bidimensional y modo Doppler colorido de un gato con cardiomiopatía hipertrófica obstructiva a partir de la vista paraesternal derecha 5 cámaras del tracto de salida del ventrículo izquierdo. (a) Note el flujo turbulento debido a la insuficiencia de la válvula mitral para el atrio izquierdo (flecha amarilla). (b) Note el flujo turbulento en la sístole en el tracto de salida ventricular izquierdo debido a una obstrucción hipertrófica en la zona subaórtica y en el atrio izquierdo debido a una insuficiencia mitral (flechas amarilla y roja, respectivamente). LVOT: tracto de salida del ventrículo izquierdo; LA: atrio izquierdo; LVFW: pared libre del ventrículo izquierdo y IVS: septo interventricular.

Another study performed by Chetboul et al $\left(2006^{\mathrm{b}}\right)$ demonstrated that conventional echocardiography was unable to detect HCM in a young Maine coon cat. In contrast, in this same study, 2D colour TDI identified a marked LVFW dysfunction, presenting with decreased

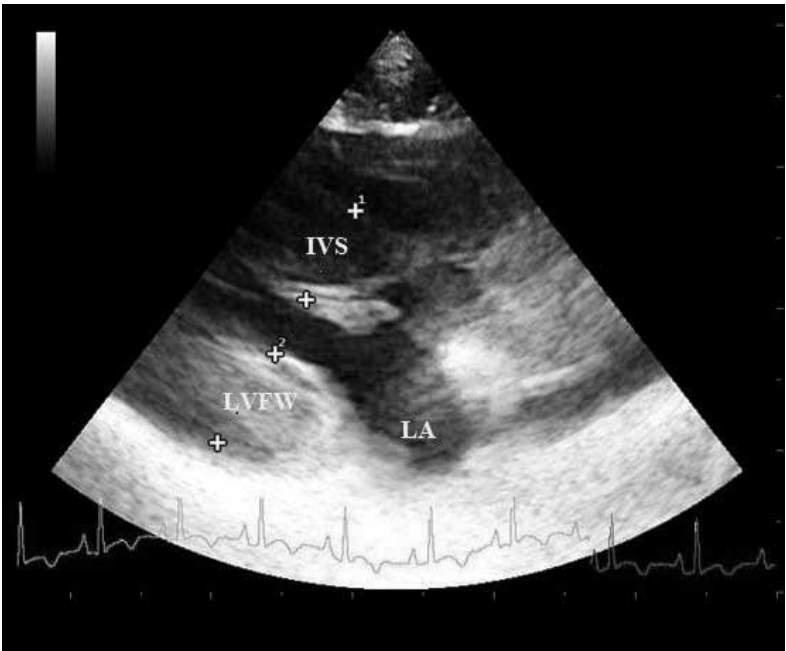

Figure 5. Two-dimensional echocardiographic examination of a cat with HCM from right paraesternal longitudinal view. Note interventricular septum and left ventricle free wall hypertrophy. LA: left atrium; LVFW: left ventricular free wall and IVS: interventricular septum.

Examen ecocardiográfico bidimensional de un felino con cardiomiopatía hipertrófica a partir de la vista paraesternal longitudinal derecha. Note la hipertrofia del septo interventricular y de la pared libre del ventrículo izquierdo. LA: atrio izquierdo; LVFW: pared libre del ventrículo izquierdo y IVS: septo interventricular.

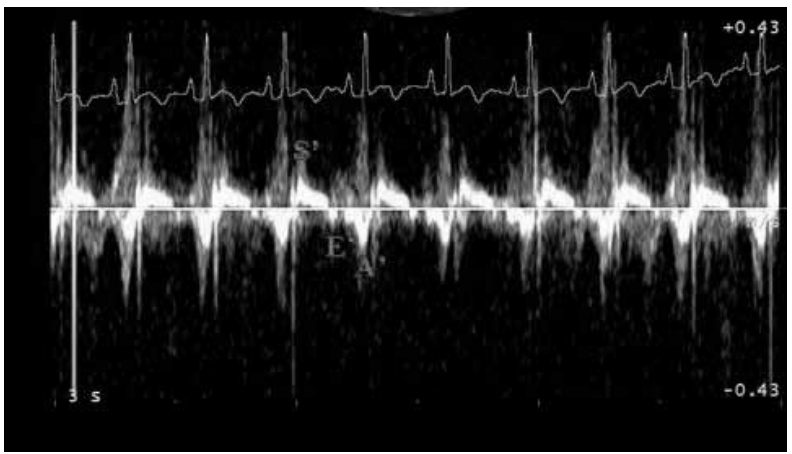

Figure 6. Pulsed tissue Doppler image tracing obtained from the basal interventricular septum along the longitudinal axis from the left parasternal 4-chamber view in a cat with HCM. Note inversion between E' wave and A' wave due to diastolic dysfunction. S': tissue Doppler systolic wave; E': peak early tissue Doppler mitral annulus velocity and A': peak late tissue Doppler mitral annulus velocity.

Imagen de rastreo en el Doppler Tejidual pulsado obtenida a partir del septo interventricular basal a lo largo del eje longitudinal de la vista paraesternal izquierda 4 cámaras en un gato con cardiomiopatía hipertrófica. Note la inversión de las ondas E' y A' debido a disfunción diastólica. S': onda sistólica del Doppler Tejidual; E’: pico temprano de velocidad en el anillo mitral por el Doppler Tejidual y A': pico final de velocidad del anillo mitral por el Doppler Tejidual.

myocardial velocities in early diastole, increased myocardial velocities in late diastole and the presence of post-systolic contractions at the base and the apex at longitudinal motion. The diagnosis of HCM was confirmed by conventional echocardiography one year after the first examination. 
Given that fining, this case demonstrated the sensitivity of TDI in the early detection of HCM.

Colour M-mode TDI allows the calculation of myocardial velocity gradient (MVG), which describes the spatial distribution of trans-myocardial velocities from the endocardium to the epicardium. A study showed that the differences between normal and HCM cats were due to decreased early diastolic and systolic MVG and corresponding peak mean myocardial velocities were similar between the two groups (Koffas et al 2008). Another study using colour M-mode TDI in cats demonstrated that similar velocity patterns occur in the LVFW of cats when compared with measurements in humans, in which this part of the myocardium shows up alternately as red and blue as it moves towards and away from the transducer, respectively. In addition, the presence of biphasic characteristics in the early diastolic movement in the LVFW of cats was observed. This movement involved the entire myocardium and was not confined to the endocardial region (Koffas et al 2003). These studies using 2D TDI colour and colour M-mode measurements showed that feline HCM was also associated with systolic myocardial dysfunction (Sampedrano et al 2006, Koffas et al 2008).

Other techniques include St and StR, and these measurements were introduced into clinical practice to evaluate regional myocardial deformation magnitudes and rates (Wess et al 2010). The term St is related to a decrease or increase in the length of a myocardial segment. Echocardiographically, St and StR allow measurements of dimensional myocardial segmental deformation (contraction or stretching) and rate of deformation, respectively (Chetboul 2010).

Wess et al (2010) demonstrated that systolic myocardial St is reduced in mild forms of feline HCM and decreases further in severe HCM. Decreased regional systolic function had previously been found in cats with mild HCM. The researchers also observed decreased St in hypertrophied and non-hypertrophied myocardial areas, similarly to humans. In addition, myocardial fibrosis was associated with impaired longitudinal St in HCM. Other changes in passive mechanical characteristics due to fibrosis and altered collagen deposition may also affect deformation. Thus, myocardial St studies in cats might be able to detect early or progressive systolic dysfunction.

Another echocardiographic tool to access myocardial function is 2D STE (Chetboul 2010). This technique has been established in humans to study HCM of various causes (Nagakura et al 2007, D'Andrea et al 2010). In dogs, it has been used to study the regional myocardial motion concomitantly in several segments and also new indices of systolic left ventricle function, such as systolic rotation, radial, and longitudinal and circumferential St and StR (Chetboul et al 2007, Chetboul et al 2008, Griffiths et al 2011, Wess et al 2011). Given those findings, 2D STE could in the future be useful in the diagnosis of feline HCM; therefore, studies of the use of this tool in cats with $\mathrm{HCM}$ are needed to evaluate its effectiveness in the diagnosis of the disease.

\section{CONCLUSIONS}

HCM is one of the most common cardiac diseases in cats. Although, in the routine, HCM diagnosis is mainly obtained using conventional echocardiography as M-mode and 2D measurements, these could make difficult to identify myocardial alterations in animals at early stages of the disease. Thus, recent echocardiographic modalities must be associated to the investigation and the TDI techniques are those that have been demonstrating better results in the early diagnosis of HCM in cats, even in absence of myocardial hypertrophy.

Two-dimensional STE is a new tool that have been used in veterinary medicine, providing new insights into myocardial function in dogs. Based on the results in humans with HCM, this tool is a promise to the diagnosis and management of this disease in cats.

Thus, this review describes the standard and new echocardiographic techniques and their benefits in the diagnosis of feline $\mathrm{HCM}$, and it may assist veterinarians in the diagnosis of the disease, since cats are one of the most popular pets in the world and the demand for specialised care for this species is increasing.

\section{SUMMARY}

Feline hypertrophic cardiomyopathy is a primary myocardial disease. Feline HCM is a disease of the ventricular myocardium characterised by mild-to-severe primary concentric hypertrophy. The disease has been attributed to hereditary factors in certain breeds and causal mutations have been discovered in the Maine coon and ragdoll breeds. However, the disease is still a challenge for clinicians because of the difficulty of early diagnosis and the risk of the sudden death of the afflicted animals. Echocardiography is the non-invasive tool of choice for the diagnosis of cardiac diseases in cats. New echocardiographic techniques such as tissue Doppler imaging (2-dimensional colour, colour M-mode, pulsed-wave mode), strain, and strain rate have proven to be effective in the early diagnosis of myocardial dysfunction, even in the absence of hypertrophy in conventional echocardiography. The aim of this review is to provide an update on information regarding the echocardiographic diagnosis of the disease.

\section{ACKNOWLEDGMENTS}

This work was partly supported by FAPEMIG (Research Support Foundation of the State of Minas Gerais), CNPq (National Council for Scientific and Technological Development), CAPES (Coordination of Improvement of Higher Education Personnel) and the Veterinary Science Postgraduate Program of the Federal University of Lavras, Brazil.

\section{REFERENCES}

Abbott JA, HN MacLean. 2006. Two-dimensional echocardiographic assessment of the feline left atrium. J Vet Intern Med 20, 111-119.

Abbott JA. 2010. Feline hypertrophic cardiomyopathy: an update. Vet Clin Small Anim 40, 685-700.

Adin DB, L Diley-Poston. 2007. Papillary muscle measurements in cats with normal echocardiograms and cats with concentric left ventricular hypertrophy. J Vet Intern Med 21, 737-741. 
Baty CJ, DE Malarkey, CE Atkins, TC DeFrancesco, J Sidley, BW Keene. 2001. Natural history of hypertrophic cardiomyopathy and aortic thromboembolism in a family of Domestic Shorthair cats. $J$ Vet Intern Med 15, 595-599.

Bonagura JD. 2000. Feline echocardiography. J Feline Med Surg 2, 147-151.

Boon JA. 2011. Myocardial diseases In: Boon J (ed). Veterinary Echocardiography. Chapter 7. $2^{\text {nd }}$ ed. Wiley- Blackwell, Iowa, USA, Pp 359-379.

Brizard D, C Amberger, S Hartnack, MG Doherr, C Lombard. 2009. Phenotypes and echocardiographic characteristics of a European population of domestic shorthair cats with idiopathic hypertrophic cardiomyopathy. Schweiz Arch Tierheilk 151, 529-538.

Campbell FE, MD Kittleson. 2007. The effect of hydration status on the echocardiographic measurements of normal cats. $J$ Vet Intern Med 21, 1008-1015.

Chetboul V. 2002. Tissue Doppler imaging: a promising technique for quantifying regional myocardial function. $J$ Vet Cardiol 4, 7-12.

Chetboul V, S Blot, CC Sampedrano, JL Thibaud, N Granger, R Tissier, P Bruneval, F Gaschen, V Gouni, AP Nicolle, JL Pouchelon. 2006a. Tissue Doppler imaging for detection of radial and longitudinal myocardial dysfunction in a family of cats affected by dystrophindeficient hypertrophic muscular dystrophy. J Vet Intern Med 20, 640-647.

Chetboul V, CC Sampedrano, V Gouni, AP Nicolle, JL Pouchelon. 2006 ${ }^{\mathrm{b}}$. Two-dimensional color tissue Doppler imaging detects myocardial dysfunction before occurrence of hypertrophy in a young Maine coon cat. Vet Radiol Ultrasound 47, 295-300.

Chetboul V, F Serres, V Gouni, R Tissier, JL Pouchelon. 2007. Radial strain and strain rate by two-dimensional speckle tracking echocardiography and the tissue velocity based technique in the dog. J Vet Cardiol 9, 69-81.

Chetboul V, F Serres, V Gouni, R Tissier, JL Pouchelon. 2008. Noninvasive assessment of systolic left ventricular torsion by 2-Dimensional Speckle Tracking imaging in the awake dog: repeatability, reproducibility, and comparison with tissue Doppler imaging variables. J Vet Intern Med 22, 342-350.

Chetboul V. 2010. Advanced techniques in echocardiography in small animals. Vet Clin Small Anim 40, 529-543.

D'Andrea A, L Riegler, G Di Salvo, R Gravino, R Cocchia, F Castaldo, G Salerno, E Golia, G Limongelli, G De Corato, S Cuomo, G Pacileo, MG Russo, R Calabrò. 2010. Right ventricular myocardial involvement in either physiological or pathological left ventricular hypertrophy: an ultrasound speckle-tracking two-dimensional strain analysis. Eur J Echocardiogr 11, 492-500.

Dümmel C, H Neu, A Hüttig, K Failing. 1996. Echocardiographic reference ranges of sedated cats. Tierarztl Prax 24, 190-196.

Ferasin L, CP Sturgess, MJ Cannon, SMA Caney, TJ Gruffydd-Jones, PR Wotton. 2003. Feline idiopathic cardiomyopathy: a retrospective study of 106 cats (1994-2001). J Feline Med Surg 5, 151-159.

Ferasin L. 2009. Feline myocardial disease: diagnosis, prognosis and clinical management. J Feline Med Surg 11, 183-194.

Fox PR, SK Liu, BJ Maron. 1995. Echocardiographic assessment of spontaneously occurring feline hypertrophic cardiomyopathy. Circulation 92, 2645-2651.

Fuentes VL. 2010. Echocardiography cardiomyopathies In: Fuentes VL, Johnson LR, Dennis S (eds). BSAVA Manual of Canine and Feline Cardiorespiratory Medicine. Chapter 11. $2^{\text {nd }}$ ed. British Small Animal Veterinary Association, London, UK, Pp 79-97.
Griffiths LG, JR Fransioli, M Chigerwe. 2011. Echocardiographic assessment of interventricular and intraventricular mechanical synchrony in normal dogs. J Vet Cardiol 13, 115-126.

Kittleson MD, KM Meurs, MJ Munro, JA Kittleson, SK Liu, PD Pion, JA Towbin. 1999. Familial hypertrophic cardiomyopathy in Maine Coon cats: an animal model of human disease. Circulation 99, 3172-3176.

Koffas H, J Dukes-McEwan, BM Corcoran, CM Moran, A French, V Sboros, T Anderson, P Smith, K Simpson, WN McDicken. 2003. Peak mean myocardial velocities and velocity gradients measured by color M-Mode tissue Doppler imaging in healthy cats. $J$ Vet Intern Med 17, 510-524.

Koffas H, J Dukes-McEwan, BM Corcoran, CM Moran, A French, V Sboros, K Simpson, WN McDicken. 2006. Pulsed tissue Doppler imaging in normal cats and cats with hypertrophic cardiomyopathy. $J$ Vet Intern Med 20, 65-77.

Koffas H, J Dukes-McEwan, BM Corcoran, CM Moran, A French, V Sboros, K Simpson, T Anderson, WN McDicken. 2008. Colour M-mode tissue Doppler imaging in healthy cats and cats with hypertrophic cardiomyopathy. J Small Anim Pract 49, 330-338.

MacDonald KA, MD Kittleson, T Garcia-Nolen, RF Larson, ER Wisner. 2006. Tissue Doppler imaging and gradient echo cardiac magnetic resonance imaging in normal cats and cats with hypertrophic cardiomyopathy. J Vet Intern Med 20, 627-634.

Nagakura T, M Takeuchi, H Yoshitani, H Nakai, T Nishikage, M Kokumai, S Otani, M Yoshiyama, J Yoshikawa. 2007. Hypertrophic cardiomyopathy is associated with more severe left ventricular dyssynchrony than is hypertensive left ventricular hypertrophy. Echocardiography 24, 677-684.

Nakamura RK, M Rishniw, MK King, CD Sammarco. 2011. Prevalence of echocardiographic evidence of cardiac disease in apparently healthy cats with murmurs. J Feline Med Surg 13, 266-271.

Paige CF, JA Abbott, F Elvinger, L Pyle. 2009. Prevalence of cardiomyopathy in apparently healthy cats. $J$ Am Vet Med Assoc 234, 1398-1403.

Payne J, VL Fuentes, A Boswood, D Connolly, H Koffas, D Brodbelt. 2010. Population characteristics and survival in 127 referred cats with hypertrophic cardiomyopathy (1997 to 2005). J Small Anim Pract 51, 540-547.

Sampedrano CC, V Chetboul, V Gouni, AP Nicolle, Jean-Louis Pouchelon, R Tissier. 2006. Systolic and diastolic myocardial dysfunction in cats with hypertrophic cardiomyopathy or systemic hypertension. $J$ Vet Intern Med 20, 1106-1115.

Schober K, A Todd. 2010. Echocardiographic assessment of left ventricular geometry and the mitral valve apparatus in cats with hypertrophic cardiomyopathy. J Vet Cardiol 12, 1-16.

Simpson KE, BC Devine, DA Gunn-Moore, AT French, J DukesMcEwan, H Koffas, CM Moran, BM Corcoran. 2007. Assessment of the repeatability of feline echocardiography using conventional echocardiography and spectral pulse-wave Doppler tissue imaging techniques. Vet Radiol Ultrasound 48, 58-68.

Wess G, R Sarkar, K Hartmann. 2010. Assessment of left ventricular systolic function by strain imaging echocardiography in various stages of feline hypertrophic cardiomyopathy. J Vet Intern Med 24, 1375-1382.

Wess G, LJM Keller, M Klausnitzer, M Killich, K Hartmann. 2011. Comparison of longitudinal myocardial tissue velocity, strain, and strain rate measured by two-dimensional speckle tracking and by color tissue Doppler imaging in healthy dogs. J Vet Cardiol 13, 31-43. 